\title{
HOLOCAUSTO E EXÍLIO: O REFUGIADO NO CORPO SOCIAL PORTUGUÊS E BRASILEIRO
}

\author{
Karina Carvalho de Matos Marques \\ (Université Paris 3 - Sorbonne Nouvelle)
}

\section{RESUMO}

Este estudo comparativo entre o romance Sob céus estranhos (1962) de Ilse Losa e o conto "A Prece" da coletânea Contos do imigrante (1956) de Samuel Rawet trata da imagem do refugiado em Portugal e no Brasil, no contexto da Segunda Guerra Mundial, suscitando uma reflexão sobre o papel desses países como terra de asilo, bem como sobre sua organização sócio-político-econômica nos anos 40-50.

PALAVRAS-CHAVE: imigração judaica, Samuel Rawet, Ilse Losa.

\section{RÉSUMÉ}

Cette étude comparative entre le roman Sob céus estranhos (1962) d'Ilse Losa et le conte «A Prece» du recueil Contos do imigrante (1956) de Samuel Rawet traite de l'image du réfugié au Portugal et au Brésil dans le contexte de la Seconde Guerre Mondiale, suscitant une réflexion sur le rôle de ces pays comme terre d'accueil, ainsi que sur leur organisation socio-politico-économique dans les années 40-50.

MOTS-CLÉS: immigration juive ; Samuel Rawet ; Ilse Losa 
O intercruzamento entre a história do holocausto e a história das sociedades portuguesa e brasileira contemporâneas não foi, até o momento, objeto de uma análise crítica comparativa no domínio da literatura. Por meio deste estudo do romance Sob céus estranhos, de Ilse Losa (1962), e do conto "A Prece", da coletêanea Contos do imigrante de Samuel Rawet (1956), ${ }^{1}$ pretendemos preencher uma pequena parte dessa lacuna acadêmica, examinando a imagem do refugiado no corpo social português e brasileiro e promovendo, assim, uma reflexão sobre o papel desses países como terra de asilo, bem como sobre sua organização sócio-político-econômica no contexto da Segunda Guerra Mundial.

Ainda que esses textos não apresentem um pacto aubiográfico explícito, neles constatamos índices de uma escrita pessoal tanto em primeira, quanto em terceira pessoa. Os protagonistas, refugiados judeus recém-instalados em Portugal e no Brasil, são porta-vozes de seus autores e de suas experiências: em 1934, fugindo da Gestapo, Ilse Losa - então uma jovem de 21 anos - deixa a sua cidade natal na Alemanha para morar no Porto; dois anos depois, Samuel Rawet - menino de sete anos - parte da Polônia, instalando-se no Rio de Janeiro com sua família. Ambos de origem judaica, sempre escreveram em português e, mesmo se o escritor brasileiro não foi uma vítima direta dos nazistas, o Holocausto é um assunto comum à obra dos dois autores.

Podemos observar que, tanto no caso do Brasil como no de Portugal, a acolhida das minorias nacionais vítimas do nazismo não foi um processo de fácil aceitação, munindo-se os dois Estados de mecanismos de seleção étnica camuflados tanto aos olhares externos, quanto aos internos. Segundo a historiadora Maria Luiza Tucci Carneiro, o episódio da Segunda Guerra Mundial promoveu uma revisão do termo "refugiado político" dentro dos acordos políticos internacionais, alargando-o aos casos de "emigração forçada”. Com relação ao recebimento de refugiados judeus, a expansão desse campo pragmático provocou uma situação desconfortável quando da conferência de Évian e da criação do Comitê Intergovernamental para os Refugiados, em 1938, já que nem todos os países estavam interessados em receber esse tipo de cidadão. No caso do Brasil, “o Estado autoritário de Getúlio Vargas (1930-1945) valeu-se de seus medos para justificar atos de intolerância e exclusão. [...] Erico Gaspar Dutra (1946-1950) manteve uma circular secreta contra a entrada de israelitas". O projeto identitário nacionalista criado no Estado Novo visava a um controle étnico sintetizado no slogan "promover o homem brasileiro e defender a paz social no país", em que não cabiam "elementos ameaçadores à composição racial e à ordem social e política brasileira”. (CARNEIRO, 2005, p. 343-344)

Do outro lado do Atlântico, a ex-metrópole possuía também o seu "Estado Novo", um regime igualmente autoritário e nacionalista com uma política de recebimento de refugiados similarmente ambígua. No controle do sistema, Antônio de Oliveira Salazar pregava uma posição de neutralidade do país durante a Segunda Guerra Mundial que se revelava, 
sob vários aspectos, completamente ilusória, como podemos verificar pela circular número 10 de 28 de agosto de 1938. Segundo a historiadora Irene Flunser Pimentel, esse documento proibia a concessão de vistos ao emigrante "impedido de regressar ao país de origem", o que enquadrava precisamente o caso dos judeus, para os quais era necessário aplicar, segundo o ministro da Legação portuguesa em Berlim, Veiga Simões, "as medidas de restrição e escolha que o visto permite efetuar" (PIMENTEL, 2006, p. 76). Assim, ainda que Salazar declare em Comment on relève un Etat ${ }^{2}$ (SALAZAR, 1937), livro em que faz apologia a seu regime, que a questão da distinção biológica de raça é considerada "lamentável" (PIMENTEL, 2006, p. 41), sua nação cujo slogan era "orgulhosamente sós" se mostrava permeável à influência dos nazistas, o que contrastava com os valores difundidos no seu lema "Deus, Pátria, Família".

Dentro dessa mentalidade conservadora, os refugiados - vindos de fora com valores considerados libertários - eram igualmente vistos como uma ameaça à integridade do povo português. Podemos, assim, verificar que o espaço-nação é criado por um discurso que articula um projeto político presente a um passado nacional partilhado, como Homi Bhabha explica: "saber dividido entre a racionalidade política e seu impasse, entre os fragmentos e retalhos de significação cultural e as certezas de uma pedagogia nacionalista" (BHABHA, 1998, p. 202). Portanto, a incorporação da identidade nacional do cidadão requer uma formação, chamada pelo autor de "pedagogia nacionalista", que reconstrói a fábula de um passado mítico atávico, à luz de um projeto político nacional presente. Ora, o estrangeiro, enquanto recém-chegado e não sendo ainda formatado dentro dos mecanismos dessa narrativa social, é incapaz de possuir o mesmo desempenho de um nativo nesse jogo de reinserção constante no corpo social do país. A pedagogia nacional que o formou é completamente outra, ela está inscrita em sua mente desde a mais tenra idade. Como complemento étnico e corporal dessa formação mental coletiva, Michel Foucault nos oferece o conceito de genealogia: "a genealogia, como análise da proveniência, está, portanto, no ponto de articulação do corpo com a história. Ela deve mostrar o corpo inteiramente marcado de história e a história arruinando o corpo" (FOUCAULT, 2007, p. 22). Em nosso estudo, observaremos o processo de integração do refugiado - enquanto corpo estrangeiro - no corpo social brasileiro e português, levando-se em consideração dois pontos de observação das forças político-históricas formadoras da identidade nacional: a pedagogia nacionalista de Bhabha - como discurso formatador da mentalidade - e a genealogia de Foucault - como discurso formatador do corpo.

No romance Sob céus estranhos, o protagonista, Josef Berger, chamado José pelos portugueses, chega ao Porto procurando um refúgio contra a violência antissemita da qual ele foi vítima na Alemanha. Após um duro período de adaptação em que pretende deixar Portugal rumo aos Estados Unidos, ele acaba por ficar no país, cedendo a oportunidade do sonho americano a seu pai, ameaçado pelos nazistas. Esse acontecimento 
muda profundamente a vida de José que, pouco a pouco, passa a penetrar na sociedade portuguesa, graças, sobretudo, à sua relação com Teresa, filha da proprietária da pensão onde ele está hospedado. O texto começa in media res com o protagonista na sala de espera do hospital onde sua mulher vai dar à luz. Esse espaço fechado, onde vida e morte caminham lado a lado e a inércia domina as pessoas, funciona como um cronotopo do espaço íntimo da personagem, sufocada no interior da sociedade portuguesa salazarista. Na presidência desse Estado, Oscar Carmona, personagem que pode ser associado ao retrato preso ao muro da sala de espera:

José esperou pelo novo salto do grosso ponteiro prateado. Onde tinha lido que o tempo passava devagar quando espiávamos? [...] Tempo. Atrás de si o Tempo, à frente de si Tempo: passado, futuro. E o presente? $\mathrm{O}$ que era o presente? O espaço invisível entre os dois traços de um minuto, de um segundo? Ou as coisas imóveis nesta sala de espera, sem porta? Estas paredes demasiado brancas? O homem na fotografia, de cara empertigada, de colarinho empertigado, de bigode à Kaiser? A mesinha, os cravos de papel, as revistas rasgadas pelo uso? [...] "Percorremos sempre o mesmo círculo. Somos alternadamente novos, velhos, vivos, mortos, e mortos, vivos, velhos e novos. Por que somos tudo aquilo que já fomos e que havemos de ser..." (LOSA, 1987, pp. 7-8)

Viu-se outra vez na saleta sem porta. Imóvel, o homem de bigode à Kaiser contemplava os cravos de papel em cima da mesinha. [...] (LOSA, 1987, p. 9)

Ainda que a história seja contada por um narrador heterodiegético, não conseguimos nesse fragmento distinguir claramente as fronteiras entre o personagem e o narrador, pois essas duas instâncias se unem em discurso indireto livre. Estamos aí no início da obra e de uma longa viagem diegética e existencial por meio da qual o sujeito tenta encontrar seu lugar no país de asilo. Paul Ricœur define o discurso indireto livre como "a mais completa integração no tecido da narração dos pensamentos e das palavras de outrem". (RICOEUR, 1984, p. 170) $)^{3}$ O narrador cede, portanto, a voz a José para que, sozinho, ele procure um sentido para seu percurso de exílio. A intriga cessa de visar o destino externo do personagem - como futuro pai - e põe em foco o universo interior de sua transformação moral.

Enquanto cronotopo do espaço íntimo do personagem, a sala de espera opera a fusão da sociedade de asilo e do país natal. José observa então uma sensação de eterno retorno, pois ele está mais uma vez mergulhado em um regime opressor. $\mathrm{E}$ as sensações de inércia e de repetição se acentuam ainda mais pelo fato de o país estar arraigado a instituições sociais seculares, tais como a igreja católica, o Estado nacional e a família patriarcal. O espírito de estagnação e de apatia desse modelo social está materializado nos móveis, na sala branca e fechada como uma jaula, nas revistas usadas e nos cravos - futuro símbolo da revolução vindoura - aqui 
ainda inanimados. Nos dois fragmentos, o mesmo retrato: a imagem de um homem imponente que usa um bigode à maneira dos kaisers, os "imperadores” em alemão. A associação do bigode à figura do kaiser é devida a Guilherme II que governou a Alemanha de 1888 até 1918 com um militarismo e um autoritarismo exacerbados, ocupando um cargo de comando como chefe do exército durante a Primeira Guerra Mundial. A forma de seu bigode se tornou um fenômeno de moda, simbolizando seu espírito bélico e autoritário. Ora, Oscar Carmona, militar e presidente de Portugal depois do putsch, de 1926 a 1951, usava o mesmo bigode. Entretanto, o verdadeiro kaiser do Estado Novo era Antônio de Oliveira Salazar, seu ministro das finanças, que concebeu o regime e o dirigia com um poder superior ao seu. É nessa atmosfera de fechamento e de paralisia que o conto começa.

Ana Isabel Marques interpreta a sala de espera onde se encontra José como uma dimensão especular da angústia da personagem desterrada: "O isolamento do sujeito, a sensação de paragem no tempo e a errância pelas memórias contêm ressaibos da síndrome da vida em trânsito, tematizada por tantos escritores do exílio" (MARQUES, 2001, p. 141). Esta análise é sem dúvida pertinente, mas nós não podemos negligenciar a insistência do autor na descrição do retrato pendurado no muro deste cômodo. Ele nos reenvia à alteridade que define o personagem como um corpo estrangeiro e, portanto, em perpétua errância. Apesar do desespero em que se encontra, o refugiado é percebido pelo povo português, ao longo de todo o romance, como um corpo expansivo, em liberdade, contra aquele dos portugueses prisioneiros de um regime opressor. No trecho seguinte, o fluxo intenso de pessoas que chegam é sentido como uma ameaça aos valores culturais portugueses:

O desembaraço com que se moviam e agiam, o descuido que manifestavam em relação ao seu arranjo, tudo isso reforçado pela inquietação de sei lá onde estarei amanhã, encontravam, para horror dos habitantes mais velhos, uma série de imitadores na gente nova. Começaram a ver-se raparigas de famílias bem instaladas em simulado négligé de penteado à "refugiada", a fumar cigarros nas confeitarias, a discutir com gestos largos. Rapazes, que até então só saíam à rua com raparigas de sua roda e sempre acompanhadas por mais alguém da família a garantir decência, mostravam-se por toda a parte com as "valdevinas", aparentemente cheias de desprezo pela tranquilidade burguesa. Essa gente estranha, espalhada pelos cafés e pelas praias, a levar uma vida de nómadas, quase de ciganos, destoava do ambiente e criava uma atmosfera de instabilidade, incerteza e angústia. Não se estaria tão seguro na sela como se tinha suposto? Poderia alguma ventania sacudir as velhas fachadas e demoli-las? (LOSA, 1987, p. 62)

Salvos do Holocausto e entregues à sua sorte, os refugiados representam - aos olhos dos portugueses - a encarnação da liberdade com 
relação a todo tipo de instituição política e social. Ainda que seu desembaraço e dinamismo sejam ligados à urgência de obter um lugar para se estabelecer, eles são percebidos pelos portugueses como corpos exuberantes e expansivos, em contraste com os portugueses - discretos e retraídos -, formatados por um regime opressor, remetendo-nos à ideia de Foucault do corpo marcado pela história e da história arruinando o corpo. Essa imagem do corpo estrangeiro fascina os jovens portugueses e representa um perigo para os mais antigos, já impregnados da pedagogia nacionalista. A presença de mulheres nos cafés choca a sociedade patriarcal salazarista. Mesmo a sua atividade profissional é condenada por Salazar: "O trabalho da mulher fora do lar o desagrega, separa os membros da família, torna-os estrangeiros uns aos outros." (SALAZAR, 1937, p. 39) ${ }^{4}$ Podemos constatar que o termo "estrangeiro" é aqui utilizado para representar o comportamento dos membros de um lar desunido. No lema do Estado Novo, a pátria e a família estão associadas ao sagrado, o que explica a imagem da casa projetada naquela do país como o reflexo do cosmos, da mãe criadora e, portanto, da proteção. Nesse sistema, o tempo da tradição deve ser preservado, por isso as instituições seculares possuem um papel fundamental. Em contrapartida, o tempo profano, visto como sinal de perigo, seria, portanto, ligado ao espaço exterior e ao alhures. Desse modo, o risco de contaminação dos jovens portugueses pelos hábitos mundanos dos refugiados constitui uma verdadeira ameaça, abrindo os círculos de relações para além do meio familiar, abalando como uma tempestade o corpo social secular ("velhas fachadas"). No trecho seguinte, podemos ver a imagem idealizada da casa antiga como a materialização do país secular:

As casas velhas, estreitas, arbitrariamente altas e baixas, de dia pitorescas com as fachadas de azulejos e os balcões de ferro, distinguindo-se agora apenas pelo contraste das dimensões, talvez evocassem alguma coisa do passado, quem sabe? Mas a um estrangeiro, como ele, não diziam nada, não lhe inspiravam essa nostalgia que podem sentir os indígenas por se suporem a continuação desse passado do qual ele, o estrangeiro, não participava, não só pela sua origem mas sobretudo porque a nostalgia de um passado histórico se cultiva na infância, tal como os usos e costumes. [...] Era por isso que às vezes, mesmo depois de viver vários anos naquela cidade, ao deambular pelas ruas punha a si próprio a pergunta: "Mas o que estou eu aqui a fazer? Por que é que ando por estas ruas?" (LOSA, 1987, pp. 15-16)

José se encontra em um momento de profunda reflexão sobre seu lugar na terra de asilo. O protagonista percebe que o sentimento de pertença a um país está diretamente ligado a uma pedagogia nacionalista da qual o estrangeiro está excluído, o que nos leva ao pensamento de Homi Bhabha. A narração social de Portugal, enquanto grande nação figurada pelas casas antigas decoradas de balcões de ferro com azulejos, não faz parte de 
sua formação cultural. Essa nostalgia exacerbada do passado, assim como o fechamento do país, explicariam o olhar dos portugueses quanto aos refugiados, associados a uma dimensão temporal mais avançada, ligada ao progresso, ao conforto e à despreocupação com relação à tradição. Todavia, isso é somente uma visão do exterior. O olhar do protagonista, enquanto refugiado, é completamente diferente:

Os grupos, sempre diferentes e no entanto sempre iguais aos olhos dos que os viam de fora, passavam agora o tempo de espera por alguma solução não só nos cafés e nas prisões mas, ultimamente, também nas Caldas das Rainhas, onde as autoridades os concentravam [...] Vinham acabrunhados, esfomeados como bichos, humilhados até à ira ou à apatia ou tomados desse azedume peculiar das pessoas que estão em disputa com o seu destino por saberem que o fantasma da abjeção infernal se intrometerá, para sempre, com riso de escárnio, entre elas e o mais breve momento de alegria e de despreocupação, condenando-as ao tormento das angústias, das visões macabras, da descrença em Deus e nos homens. Ainda dominados pelo medo e pelas ameaças, suspeitando em cada indivíduo um criminoso ou um denunciante, só de noite, atrás das portas fechadas e depois de se terem certificado repetidas vezes de não haver escutadores escondidos, relatavam febrilmente, de olhos assombrados e mãos trémulas, o que viram e o que suportaram. (LOSA, 1987, p. 88)

Nesse fragmento, é o próprio José que nos oferece a imagem de seus compatriotas. Nesse seu testemunho, não é a imagem de exuberância, de despreocupação ou de independência que nós vemos, mas de impotência, de retração e de perturbação. O passado assombra esses indivíduos em visões satânicas, desestabilizando sua estrutura corporal e sua percepção da realidade. Em território português, à semelhança dos campos de concentração nazistas - ainda que de uma forma muito mais humana -, eles são igualmente privados de liberdade, encarcerados em prisões ou "zonas de residência fixa", como em Ericeira e em Caldas da Rainha. Esta foi criada em 1942 para concentrar os estrangeiros que não tinham visto, com um documento ilegal ou vencido. Analisando de forma comparada o seu olhar pessoal com aquele que os nativos fazem dos refugiados, José tem um papel de tradutor cultural. Ele se aproxima, portanto, cada vez mais desse corpo social, fato que nós podemos constatar no fragmento seguinte, em que as fronteiras do país tocam-no metaforicamente:

Acontece assim quando as fronteiras deste pequeno país me tocam no corpo e experimento a sensação de estar preso num cárcere feito de princípios e conceitos mesquinhos, de injustiças grosseiras, de sonolenta insipidez. Acontece quando me falta a compreensão pelos miseráveis que, numa atitude de resignação in- 
digna, me estendem o seu sorriso servil ou a mão para uma esmola. Acontece quando a vida em público, decorrendo sem a presença de mulheres, me simboliza atraso, enfado, falta de espírito e de graça, e apetece-me então romper com as grades, respirar mais fundo, em qualquer parte onde haja resistência e luta, renovação e aventura, ou pelo menos um pouco mais de exuberância. (LOSA, 1987, p. 165)

Nesse monólogo interior, "a magia da transparência interior" (RICOEUR, 1984, p. 171) ${ }^{5}$ do protagonista sobressai, fazendo-nos ver uma conexão profunda com o povo de sua terra de exílio. José olha-os de frente - o sorriso, a mão estendida -, colocando-se em sua pele. É o princípio ético por excelência do testemunho, pois José esquece a si mesmo e a seu grupo, falando em nome de uma comunidade que não é a sua: "trata-se de tornar presente a alteridade (do testemunhado, da testemunha)" (CHIANTARETTO, 2002, p. 12). ${ }^{6}$ Ele se vê capaz de analisar a pedagogia nacionalista desse país, incitando o povo a romper com esse discurso. Na última parte do livro, seu desejo de ver a nação sair da clausura e se recriar se transforma em ação. Ele deixa a sala de espera, percorrendo um corredor escuro até perceber o único cômodo iluminado: aquele onde está Teresa. Ali ele encontra sua esposa que acaba de dar à luz a um menino. A figura do narrador reaparece, então, como no início do romance, para contar a história do refugiado transformado pela paternidade:

José aproximou-se do berço com rendinhas e folhinhos. "Horrível berço", pensou. O menino respirava quase imperceptivelmente, e a cabeça morena realçava-se-lhe da roupa muito branca. Na Alemanha achá-lo-iam exótico. [...] "Se fosse na minha terra não me deixavam dormir no mesmo quarto com a Teresa e o menino. [...] Aqui as coisas passam-se de outra maneira, menos racional; somos como pássaros num ninho ou como a Santa Família no curral de Belém.

Abriu a janela. A chuva lavara o ar. Era difícil adivinhar se o tempo se manteria bom. "Um filho é continuação. Ou chegada? [...] O amor a outros seres, a continuação em outros seres, a ilusão de segurança e estabilidade ou somente uma estação intermédia na eterna fuga do homem? Não sei, não sei....”

Fechou de novo a janela e depois as portas para que a luz que ia sendo mais forte não incomodasse Teresa. (LOSA, 1987, p. 182)

José inicia um processo de incorporação à sociedade portuguesa. O corpo mesmo de seu filho - prolongamento do seu - carrega os traços daquele dos autóctones: "cabeça morena". O fato de que na Alemanha seu descendente seria reconhecido como exótico produz uma visão de si mesmo como um outro, um "eu" "despegado com relação a todos os referenciais espaço-temporais solidários do corpo" (RICOEUR, 1990, p. 16), 
libertando-o assim de uma genealogia que o prende à sua origem judaico-alemã e à sua história pessoal trágica.

Dessa forma, o nascimento de seu filho e a constituição de um lar significam para José a sacralização do tempo profano ligado à história trágica do Holocausto ("Santa Família no curral de Belém”). A casa, enquanto imago mundi e réplica do corpo humano, opera a inserção do protagonista no corpo social desse país. A janela aberta e a presença da chuva reforçam essa ideia de renascimento em um novo corpo. Entretanto, José coloca em questão a imobilidade dessa moradia ("chegada"), contra a ideia de um abrigo provisório ("continuação"), o que nos faz pensar em seus questionamentos sobre a sociedade portuguesa. A ideia de seu prolongamento no corpo de seu filho e a ação de fechar a janela para proteger Teresa nos reenvia ao início do romance, à sala de espera branca e fechada onde o tempo rodava em círculos. A imagem de um eterno retorno aqui sugerida é "antes de tudo vitória sobre o ressentimento, possibilidade de querer o que foi, de mudar tudo 'assim foi' em 'assim eu quis que isso fosse' - amor fati”. (AGAMBEN, 2003, p. 108) ${ }^{8}$ Isso não significa de forma alguma um sentimento de resignação, mas a ética do olhar frontal, do face a face, uma análise dos homens em retrospectiva, rumo ao tempo ontológico da narração social que os construiu.

Assim como no texto de Ilse Losa, no conto de Samuel Rawet a inserção do corpo estrangeiro no corpo social da terra de exílio está no cerne da narrativa. Ida, recém-chegada ao Brasil, perdeu toda a sua família na guerra. Pelos olhos do narrador heterodiegético temos logo de início uma visão do status topográfico marginal desse personagem dentro da sociedade brasileira, como habitante do "casarão", nome eufemístico para um cortiço. Esse espaço decadente, onde os meninos andam sozinhos em bandos, revela a negligência da autoridade do Estado e da família, reenviando-nos à biografia do autor. Samuel Rawet viveu até a idade de vinte anos na periferia do Rio de Janeiro, fato sobre o qual comenta: "O subúrbio está muito ligado a mim. Aprendi o português na rua, apanhando e falando errado." (RAWET, 2004, p. 10). É dentro desse mesmo clima de agressividade e de desregulamento das instituições que a juventude no poder recebe Ida, percebida como uma inimiga: "A entrada do pátio, muro que um caminhão arriou, ninguém mais levantou, Zico juntou a molecada. - Aí a velha aí!" (RAWET, 2004, p. 31). O líder do grupo, Zico, o menino mais velho, reúne os amigos no pátio do cortiço para receber Ida a pedradas.

À imagem do texto de Ilse Losa, nós temos aqui um conto que começa in media res e em que, pouco a pouco, a ação se interioriza à procura de um sentido para a vida de Ida na terra de asilo. O muro caído pode ser interpretado como o primeiro sinal de ausência de limites entre os indivíduos desse espaço: tudo é assunto de todos, o pessoal e o coletivo se confundem. Nesse sentido, o cortiço pode ser compreendido como um microcosmo do país: "numa sociedade em que a privacidade não é um valor consolidado, não há espaço para o desenvolvimento de uma consciên- 
cia individual diferenciada - e angustiada -, nem para a procura de raízes individuais" (SORJ, 1997, p. 20). A criação do homem brasileiro implica a perda da tradição e o esquecimento do passado, a confusão entre as convicções individuais e coletivas, o que opõe radicalmente Ida, enquanto judia, aos habitantes do cortiço, já formados dentro dessa pedagogia nacionalista. No trecho seguinte, vemos a protagonista entrando no cortiço onde enfrentará os garotos. O narrador caminha no ritmo da protagonista, a narração em travelling, penetrando depois no pensamento dos personagens:

Dobrando a esquina, o xale preto envolvia o pescoço enquanto as mãos duras retesavam-se ao longo do corpo, estendidas por dois pacotes imensos. O passo apressado, pisadas firmes de sapatos sem saltos, furou os olhares dos moleques, que a susto, só lhe viam o perfil marcado e os cabelos grisalhos, repuxados em coque. Nunca tiveram coragem de olhá-la de frente, e quando lhe atiraram a primeira pedra, raspando nos pés, na expectativa de ouvir a língua enrolada, só encontraram um olhar pálido e uma boca crispada. $\mathrm{O}$ gozo antevisto e frustrado deixou-os sempre à espera. Por isso a encaravam de perfil, ou então iam espioná-la pela janela. Zico, o mais velho, garantia. Conhecia os trinta moradores do sobrado, e nunca ouvira falar de caso semelhante. (RAWET, 2004, p. 31)

Em primeiro plano, a silhueta de Ida é o estereótipo da viúva segundo a tradição judaico-cristã: o xale preto e os cabelos grisalhos em coque. Seu corpo denota grande tensão: as mãos tesas, os passos apressados e firmes, o olhar perfurante. Toda a violência da qual foi vítima em sua terra natal se repete agora em sua terra de asilo, operando um processo de "semiotização do corpo, ao mesmo tempo em que ocorre uma somatização da história" (LEVY, 2007, p. 74), o que nos reenvia ao conceito de genealogia de Foucault. Agredida a pedradas como Maria Madalena, em um primeiro momento ela não ousa se exprimir: enquanto estrangeira sua palavra seria sua condenação. Para reconhecer a origem de um indivíduo, os gregos, em particular depois da guerra com os persas, baseavam-se no domínio da língua grega. A expressão verbal opunha, portanto, os gregos, "nós", e os bárbaros, "os outros, os inimigos" (cf. TODOROV, 2008, p. 33). As crianças do cortiço utilizam a mesma estratégia de guerra para excluir Ida do grupo de residentes ("trinta moradores do sobrado, e nunca ouvira falar de caso semelhante"). Um dos eixos ideológicos do governo varguista, a partir dos anos 30, foi a formulação de um projeto cívico para engendrar o "novo homem brasileiro", o que justificava "as restrições de falar em público, ensinar e publicar em línguas consideradas estrangeiras" (CYTRYNOWICZ, 2005, p. 300). A associação de Ida ao mito da santa prostituta pode se explicar pela atitude de rejeição dessa mulher que não entra no modelo cívico brasileiro, detectada como estrangeira - e, logo, como inimiga - pelo fato de não falar português. Se na obra de Ilse Losa o refugiado e o nativo se olham face a face, naquela de Samuel Rawet é um olhar atravessado que domina essa 
relação. Mais adiante no texto, vemos Ida ousando, finalmente, responder aos ataques dos meninos. Sua deficiência linguística provoca o riso, mas é o seu olhar frontal que tem o poder de fazê-los calar:

O coque virou e aos trancos uma saraivada de respostas. Pior. O riso aumentou. A chacota também. Brito coçando a barriga, gargalhava, continuando a dialogação, num estridar e ganir, latidos ao meio. Ao subir o degrau, uma pedra roçou-lhe o tornozelo. O giro do coque despejou-lhe um olhar pálido e a boca crispada. Silêncio repentino. Brito coçava a barriga em câmera lenta até parar. Um peso imobilizou-os instantaneamente [...] (RAWET, 2004, p. 32)

Podemos perceber nesse trecho que o narrador se coloca atrás da protagonista - o que explica a perspectiva de seu coque -, acompanhando a rotação de sua cabeça até que seus olhos encontrem o olhar dos meninos. Contra a covardia das crianças que a atacam pelas costas, rindo como animais, ela lhes oferece o gesto humano e corajoso de um olhar frontal. A revelação de sua alma apagada pela dor os petrifica, como se a força da tragédia lhe tivesse dado um poder de Medusa. O narrador, como um cameraman, capta a reação de Brito face a esse olhar, fazendo reduzir esses movimentos até a imobilização total. Depois desse episódio, Ida vai para o seu quarto, seu único refúgio contra a violência da comunidade do cortiço. A exclusão da protagonista pelo grupo é representada pela posição desse cômodo, localizado no fundo do imóvel, constituindo um segundo índice topográfico de marginalidade. Assim sendo, ela está numa posição marginal mesmo com relação àqueles que já são marginalizados socialmente. Nesse espaço íntimo, o narrador mergulha, em discurso indireto livre, nos pensamentos e sentimentos do personagem. A ação se volta para o seu interior em um movimento conduzido por um exercício de memória. O sabá que se aproxima opera uma sacralização do tempo:

O xale preto caído nas costas inundava-lhe o rosto. Sexta-feira! Quatro horas! Meu Deus! (...) Levantou a tampa da panela e um vapor de carne cozida aqueceu-lhe o rosto. Remexeu o fogareiro, avivou o fogo com mais carvão e um abano, e numa caçarola de água fervendo despejou as duas postas de peixe. Na cama desmanchava os pacotes, arrumando em caixas, as meias, lenços, pedaços de sabão, pacotes de grampo, cadarços, fitas... um mundo! Seu mundo! Na parede os olhos de Isaías, em prece, assustaram-se com o tlic da fotografia. [...] Agora pendia amarelado, a mancha da barba, as sobrancelhas arqueadas e uns olhos de susto. Dos outros nada mais ficara. Os olhos de Ida tremeram na lembrança. Que pesadelo! [...] Filhos já os tivera, marido também. De tudo, só o retrato ficou na parede. E ela. No rosto marcado de rugas, um sofrimento triturado. Esquecia. Morreram-lhe todos com a guerra. Sem saber como saltou um dia no porto 
daqui. Deixava uma existência inteira para trás. [...] De uma gaveta, desenrolando a flanela, tirou dois castiçais prateados, e acariciou-os com uma tremedeira nos dedos. [...] Amarrou um lenço branco, enorme, na cabeça, e, acesas as velas, seus olhos se fecharam, com o corpo em balanço. (RAWET, 2004, p. 33)

Assim como a sala de espera onde José se encontrava, o quarto de Ida funciona como um cronotopo de sua vida no cortiço, isolada e em desajuste com o tempo social. Para Ida, esse espaço adquire um valor especialmente significativo na sexta-feira, pois enquanto judia ele deve se refugiar em seu quarto para celebrar o sabá. O sétimo dia da semana aparece na Bíblia como o apogeu da criação do mundo (Gn 2, 1-3 ; Ex 20, 10), colocado em paralelo com a libertação dos hebreus do Egito. Do pôr do sol da sexta-feira até aquele de sábado, segundo o quarto dos Dez Mandamentos, Deus exalta os judeus a observar o sabá: "Quanto a você, fale aos filhos de Israel dizendo 'Você observará, sobretudo, meus sabás, pois é um sinal entre mim e você seguindo gerações para saber que eu, o Eterno, santifico-vos"' (WIGODER, 1996, p. 176) ${ }^{9}$ (Ex 31, 13-17). A narração social dos judeus constrói um lugar especial a esse ritual do qual a dimensão temporal remonta à criação do mundo. Como podemos ver no conto, Ida a respeita segundo os costumes antigos, comendo peixe, alimento essencial que faz referência à alimentação dos hebreus no Egito. $\mathrm{O}$ ritual asquenaze característico da sexta-feira à noite comporta também a carne, que deve ser colocada sobre o fogo antes do sabá. Segundo a 37ª proibição talmúdica, a comida não pode ser esquentada nesse dia. A toalha branca, o lenço cobrindo os cabelos, o balanço do corpo em oração e, sobretudo, as duas velas - referência ao exercício de memória - são símbolos judeus igualmente importantes nesse dia (WIGODER, 1996, p. 179-181). Assim, o dever de memória pregado pelo judaísmo é muito forte em Ida, não apenas por sua fé religiosa, mas por seu destino como sobrevivente do Holocausto. Da mesma forma que o retrato de Oscar Carmona na sala de espera, o de Isaías vela para que o passado não seja esquecido. Essa imagem é carregada de um grande valor simbólico, pois nós vemos aí Isaías com os olhos aterrorizados como se previsse o horror que iria se abater sobre seu povo. Os olhos de Medusa de Ida, projeção daqueles de seu marido, atualizam esse terror. A violência não podendo ser expressa verbalmente, é o olhar que a exprime: "De fato, os civilizados falam, os bárbaros se calam, a violência é sempre silenciosa" (BATAILLE, 2011, p. 196) ${ }^{10}$ o que podemos constatar no trecho seguinte em que o silêncio de Ida contrasta com o barulho do cortiço:

Uma algazarra no pátio. Correrias pela casa. Gritos, cantoria saindo do tanque. Uma rádio no andar de cima despejava sambas. Em meio à vibração Ida parada junto à janela, perdida, sem língua, sem voz. Enfiada numa vida que nunca fora a sua. [...] Ave-Maria no andar de cima, e o quarto quase às escuras. [...] A princípio receberam-na em casa de alguém, mas 
como novidade, bicho raro de outras terras que têm histórias para mais de um mês. As histórias cansaram. A bondade também. (RAWET, 2004, p. 33)

A confusão de sons nos diferentes andares do imóvel nos reenvia à imagem de uma Torre de Babel à brasileira ("samba", "Ave-Maria"). De fato, a amálgama de raças, de ritmos e de religiões distintas e a ausência de fronteiras entre o sagrado e o profano reforçam a imagem do cortiço como microcosmo desse país. Ida, no seu apego a histórias passadas, é aqui percebida como um animal exótico que atrai o interesse das pessoas. Entretanto, a cordialidade inicial dos residentes para com a recém-chegada se transforma em incompreensão que se degenera em violência. Além do fator linguístico, sua pertença religiosa é igualmente percebida como uma ameaça ao corpo social do cortiço:

Na mesa ajustava as velas, sem ver uns olhos miúdos, espremidos, respiração presa, agarrados à janela. (...)

- Tu viu?

- Vi! A gringa tinha um jeito esquisito!...

- Tu foi trouxa!...Devia dar pedra na janela.

- Não chateia! Eu estou é invocado com um troço...

- Que é?

- Esse negócio de vela...

Um frêmito atravessou o casarão de ponta a ponta. [...] A molecada em três tempos, numa quase ubiquidade, levantara o sobrado. As mulheres excitadas tomavam a frente, em meio ao choro de algum berço deixado repentinamente. Os homens, curiosos, iam atrás, assombrados com a novidade. (RAWET, 2004, p. 33-34)

Comparados a espiões em missão, os garotos observam Ida preparando no seu quarto o ofício do sabá. Ignorando totalmente essa celebração, eles a interpretam como um ritual de magia negra. Os habitantes do cortiço, gente ingênua e supersticiosa, lançam-se em uma caça às bruxas organizada pelas crianças. Vemos aí uma clara inversão hierárquica, pois os mais jovens, seguidos das mulheres, tomam a frente. Isso nos faz pensar na dimensão temporal do projeto de uma identidade brasileira em que o novo adquire um estatuto mais valoroso do que o antigo. No trecho seguinte, o grupo de residentes transgride o espaço íntimo da protagonista a fim de desvendar o segredo da suposta bruxa:

- Arreia a porta!

As mãos espalmadas nos olhos, e o lenço na cabeça, Ida jorrava a prece com o corpo em balanço sobre as velas. Hoje, Ida não pedia a Deus, mas com as mesmas palavras, gritava, ofendia (...) Tinha entre os olhos e a palma das mãos, plasmados no escuro, o rosto de 
Isaías e dos filhos, de Isaías quase um santo. Quando baixou os braços, a multidão encontrou as lágrimas fartas. Um silêncio deixou-os imóveis, e uma sensação de mal-estar, incômoda, esfriara os ânimos. Ida era um monte de nervos em relaxamento, sem força para mover os lábios. (...)

- Vamos sair, minha gente. Não é nada! (...)

- Isso é a reza lá da terra deles. (RAWET, 2004, p. 34-35)

Uma vez a barreira íntima transpassada, nós descobrimos a protagonista rezando. Compenetrada nessa ação, ela nem se dá conta da presença dos intrusos. Em seu diálogo com Deus, ela não lhe fala em tom de agradecimento, mas, ao contrário, ousa se exprimir contra a vontade divina. Seus insultos são uma oposição frontal ao poder do Criador, marcando o fim de sua aliança com o sagrado. Desse modo, os olhos chorosos de Ida podem ser interpretados como o esvaziamento das crenças que a constituem. Como pudemos ver ao longo desta análise, eles são igualmente o meio mais forte de exprimir seu sofrimento aos habitantes do cortiço. É por isso que, face à força desse sentimento, os invasores se calam, imóveis. Assim, o gesto de fuga, preservando a intimidade da protagonista, revela a impossibilidade de assimilar a dor desse corpo estrangeiro no corpo social do cortiço. A prece de Ida pode ser tomada como um apelo de socorro - "a manifestação das carnes revoltas de horror e o chamado desesperado ao fundamento" (DUFRÉNOIS; MIQUEL, 1996, p. 103) ${ }^{11}$ ao qual os habitantes do cortiço não podem responder, preferindo empurrar o problema a um alhures ("terra deles"). Nas últimas linhas do conto, vemos a imagem da desintegração do corpo da personagem, remetendo-nos àquela da "história arruinando o corpo" proposta por Foucault. Voltemos à ficção:

De dentro, vinha uma sensação de rutura, de algo que se tinha perdido com a prece gritada. (...) Um estreitamento da garganta fê-la soltar com um soluço tudo que lhe boiava no interior. Sentiu-se oca. Os dedos magros se entrelaçavam e com os dois punhos fundidos esfregou a testa. Oca. Soprou as velas uma a uma, serena, calma. Sentada diante dos castiçais, os olhos de Ida miravam os tocos apagados, e seguindo as linhas das gotas de cera, glóbulos amontoados em miniaturas estranhas, a cabeça tombou silenciosa na toalha branca. (RAWET, 2004, p. 35)

Esvaziada de todo o seu fundamento e incapaz de se integrar no corpo social do país, Ida se consome até a anulação total, como a vela que funde. A luz da alma soprada, aquela dos olhos de Ida, se apaga completamente. Finda a sua força vital, seu corpo se arruína aos poucos, como as gotas de cera que caem. Seguindo os contornos dessa imagem, o narrador, em discurso indireto livre, acompanha o movimento da protagonista do interior ao exterior e de alto a baixo. A queda de sua cabeça sobre a toalha 
branca subverte a mensagem do sabá, já que aqui é impossível "se lembrar" e se integrar sem capitular.

Contrariamente ao personagem José na sala de espera do hospital, Ida não encontra saída à clausura de seu quarto. A dimensão temporal da identidade judaica não lhe permite pertencer a um país em que a tradição é vista como uma ameaça. Ainda que na maior parte dos mitos de fundação nacional o inimigo seja o estrangeiro, no caso do Brasil, "o inimigo é interno, o próprio passado, personificado nos agrupamentos humanos associados a ele" (SORJ, 1997, p. 16). Porque Ida insiste em preservar sua religião, sua língua, seus hábitos culturais, enfim sua memória, ela é associada a esse medo histórico.

Se o tempo da narrativa de Ilse Losa nos dá a sensação de um eterno retorno, aquele de Samuel Rawet nos transmite a imobilidade. $\mathrm{O}$ movimento constante que José faz rumo à sua vida anterior implica o engajamento ético de olhar o seu passado a partir das questões que ele se coloca no presente. Ele se indigna com a política salazarista e com o futuro dos portugueses, assim como o fazia na Alemanha com relação aos nazistas. No caso de Ida, ela transplantou sua existência passada para o território brasileiro, vivendo alienada dos problemas do cortiço. Não tendo forças para sair da prisão de sua dor, ela vive constantemente no passado. Se, por um lado, ela não vai ao encontro dos nativos, seus vizinhos também não vão até ela.

A questão da integração do estrangeiro no corpo social português e brasileiro nos parece, portanto, estreitamente ligada aos projetos de identidade nacional desses países, que formatam um cidadão modelo de acordo com uma pedagogia nacionalista, aprisionando-o à sua genealogia. Na sociedade portuguesa salazarista, a valorização das instituições seculares - "Deus, Pátria, Família" - implica o isolamento do país, dificultando ao alóctone o acesso a essas instituições. Sua integração depende muito mais de um esforço pessoal de aproximação dos valores por elas transmitidos. Em sentido inverso, a política varguista prega a fusão total do recém-chegado no corpo do estado, impelindo-o a esquecer suas tradições e reivindicações étnicas ou religiosas. Cabe ao estrangeiro de se "des-identificar" ou de ficar à margem. Por meio de suas obras, Samuel Rawet e Ilse Losa nos incitam a repensar esses projetos sociopolíticos nacionais, cedendo a palavra aos indivíduos recém-chegados a essas nações, capazes, portanto, de analisá-las com "um olhar de fora".

\section{REFERÊNCIAS BIBLIOGRÁFICAS}

AGAMBEN, Giorgio. Ce qui reste d'Auchwitz. Paris: Éditions Payot \& Rivages, 2003.

BATAILLE, Georges. L'Érotisme. Paris: Les Éditions de Minuit, 2011.

BHABHA, Homi. O Local da cultura. Belo Horizonte: UFMG, 1998. 
CARNEIRO, Maria Luiza Tucci. Imigrantes e refugiados judeus em tempos sombrios: Brasil, 1933-1948. In: GRINBERG, Keila. Os Judeus no Brasil. Inquisição, imigração e identidade. Rio de Janeiro: Civilização Brasileira, 2005.

CHIANTARETTO, Jean-François. Lécriture de soi peut-elle dire l'histoire? Paris : BPI/ Centre Pompidou, 2002.

CYTRYNOWICZ, Roney. Cotidiano, imigração e preconceito: a comunidade judaica nos anos 1930 e 1940. In: GRINBERG, Keila. Os Judeus no Brasil. Inquisição, imigração e identidade. Rio de Janeiro: Civilização Brasileira, 2005.

DUFRÉNOIS, Huguette; MIQUEL, Christian. La Philosophie de l'exil. Paris: L'Harmattan, 1996. Graal, 2007.

FOUCAULT, Michel. Microfísica do poder. Rio de Janeiro: Edições

LOSA, Ilse. Sob céus estranhos. Porto: Afrontamento: 1987.

LEVY, Tatiana Salem. Andar e estar só: corpo e imigração em Samuel Rawet. In: KIRSCHBAUM, Saul (org.). Dez Ensaios sobre Samuel Rawet. Brasília: LGE Editora, 2007.

MARQUES, Ana Isabel. Paisagens da Memória: identidade e alteridade na escrita de Ilse Losa. Coimbra: Edições Minerva, 2001.

PIMENTEL, Irene Flunser. Judeus em Portugal durante a II Guerra Mundial. Em Fuga de Hitler e do Holocausto. Lisboa: A Esfera dos Livros, 2006.

RAWET, Samuel. Contos e novelas reunidos. Rio de Janeiro: Civilização Brasileira, 2004.

RICOEUR, Paul. Temps et Récit. 2. La configuration dans le récit de fiction. Paris: Éditions du Seuil, 1984.

. Soi-même comme un autre. Paris: Éditions du Seuil, 1990.

SALAZAR, Président. Comment on relève un État. Paris: Flammarion, 1937.

SORJ, Bernardo. Sociabilidade brasileira e identidade judaica. Rio de Janeiro: Imago, 1997.

TODOROV, Tzvetan. La peur des barbares: Au delà du choc des civilisations. Paris: Rober Laffont, 2008.

WIGODER, Geoffrey. Dictionnaire Encyclopédique du Judaïsme. Paris: Éditions Robert Laffont, 1996. 


\section{NOTAS}

1 Todas as referências à obra de Ilse Losa e Samuel Rawet serão colocadas no próprio texto seguindo o padrão: LOSA, 1987 (equivalente à edição de Sob Céus Estranhos. Porto: Afrontamento, 1987), seguida do número da página; RAWET, 2004 (equivalente à edição de Contos e Novelas Reunidos. Rio de Janeiro: Civilização Brasileira, 2004), seguida do número da página. Nas citações do texto da autora, respeitamos a ortografia do português europeu, conservando especificidades fonéticas mantidas após a reforma ortográfica.

2 Obra escrita originalmente em francês para o pavilhão de Portugal na Exposição Internacional de Paris. Só muitos anos depois, já no regime democrático, em 1977, viria a ser vertida para português. Em 2007, uma nova edição do livro foi publicada (Presidente Salazar. Como se Reergue um Estado. Lisboa: A Esfera do Caos, 2007), incluindo, além da reprodução da versão original do texto em língua francesa, o manuscrito do discurso proferido em Braga por ocasião do décimo aniversário do golpe militar de 28 de maio de 1926.

3 Tradução do autor do texto original em francês: "la plus complète intégration au tissu de la narration des pensées et des paroles d'autrui".

4 Tradução do autor do texto original em francês: "le travail de la femme en dehors du foyer désagrège celui-ci, sépare les membres de la famille, les rend étrangers les uns aux autres".

5 Tradução do autor do texto ao original em francês: "la magie de la transparence intérieure".

6 Tradução do autor do texto original em francês: “il s’agit de rendre présente l'altérité (du témoigné, du témoin)".

7 Tradução do autor do texto original em francês: “un 'je’ (...) désancré au regard de tous les repères spatio-temporels solidaires du corps".

8 Tradução do autor do texto original em francês: "avant tout victoire sur le ressentiment, possibilité de vouloir ce qui a été, de changer tout 'ainsi fut-il' en un 'ainsi ai-je voulu que cela fût' - 'amor fati'”.

9 Tradução do autor do texto original em francês: "Quant à toi, parle aux fils d'Israël en disant : «Vous observerez surtout mes chabbats; car c'est un signe entre moi et vous suivant vos générations pour savoir que moi, l'Éternel, je vous sanctifie." (Geoffrey Wigoder. Dictionnaire Encyclopédique du Judaïsme. Paris: Éditions Robert Laffont, 1996, p. 176)

10 Tradução do autor do texto original em francês: "En effet les civilisés parlent, les barbares se taisent, la violence est toujours silencieuse".

11 Tradução do autor do texto original em francês: "la manifestation des chairs révulsées d'horreur et l'appel désespéré au fondement". 